\author{
Abstracta Iranica \\ Abstracta Iranica Revue bibliographique pour le domaine irano-aryen \\ Volume 34-35-36 | 2017 \\ Comptes rendus des publications de 2011-2013
}

\title{
G. Rougemont. Les inscriptions grecques d'Iran et d'Asie centrale. Bilinguismes, interférences culturelles, colonisation
}

Rémy Boucharlat

\section{(2) OpenEdition}

Journals

Édition électronique

URL : http://journals.openedition.org/abstractairanica/41800

DOI : 10.4000/abstractairanica. 41800

ISSN : 1961-960X

Éditeur :

CNRS (UMR 7528 Mondes iraniens et indiens), Éditions de l'IFRI

Référence électronique

Rémy Boucharlat, « G. Rougemont. Les inscriptions grecques d'Iran et d'Asie centrale. Bilinguismes, interférences culturelles, colonisation ", Abstracta Iranica [En ligne], Volume 34-35-36 | 2017, document 16, mis en ligne le 30 décembre 2016, consulté le 26 septembre 2020. URL : http:// journals.openedition.org/abstractairanica/41800; DOI : https://doi.org/10.4000/abstractairanica. 41800

Ce document a été généré automatiquement le 26 septembre 2020

Tous droits réservés 
G. Rougemont. Les inscriptions grecques d'Iran et d'Asie centrale. Bilinguismes, interférences culturelles, colonisation

Rémy Boucharlat 


\section{RÉFÉRENCE}

G. Rougemont. « Les inscriptions grecques d'Iran et d'Asie centrale. Bilinguismes, interférences culturelles, colonisation ». Journal des Savants, 2011, p. 3-27.

1 L'A. des Inscriptions grecques d'Iran et d'Asie centrale (Corpus Inscriptionum Iranicarum, Part II, volume I, 2012) part du constat apparemment simple : « La domination grécomacédonienne est une chose, la présence effective des Grecs dans cette région du monde en est une autre, l'influence (profonde ou non, durable ou non) de la civilisation grecque en est encore une autre » (p. 8). La langue grecque, déjà présente en Iran sous les Achéménides, perdure encore $a u \mathrm{I}^{\mathrm{er}} \mathrm{s}$. de n.è. à Suse et ailleurs, comprise par une certaine population. Le choix de s'exprimer dans une langue ou une autre et surtout dans les deux, reflète des circonstances, des positions sociales ou des objectifs qu'il est souvent difficile d'analyser. Les textes trilingues (parthe, moyen-perse et grec) de Šāpūr I ${ }^{e r}$ à Naqš-e Rostam, ou des édits de l'empereur Maurya Aśoka (prakrit, araméen et grec) en Afghanistan et Pakistan s'expliquent assez aisément par l'idéologie royale et le souci d'être compris. D'autres textes en grec seulement, ou comportant du grec, plus modestes, commerciaux ou religieux, sont rédigés dans une langue de qualité comme ailleurs dans le monde grec. Ils relèvent de populations certainement minoritaires, Grecs d'origine ou hellénisés, faisant sans doute partie de l'élite qui, parce qu'ils sont loin du monde grec, veulent maintenir la pureté de la langue. L'A. propose une piste en comparant cette attitude au phénomène de nature coloniale à l'époque moderne.

\section{AUTEURS}

\section{RÉMY BOUCHARLAT}

CNRS, Lyon 